\title{
Teachers' Experiences Regarding Parental Involvement in Classroom Assessment
}

\author{
Mantsose Jane Sethusha \\ Department of Early Childhood Education \\ University of South Africa (UNISA, PO Box 392 Pretoria 0003 \\ Email: sethumj@unisa.ac.za
}

\section{Doi:10.5901/mjss.2014.v5n10p472}

Abstract

This research aimed to explore and understand teachers' experiences regarding parental involvement in classroom assessment. The study employed a qualitative design and a case study approach. Semi-structured interviews were used to elicit data from the teachers. The study utilized the conceptual framework based on the work of Epstein (2008) in which the following six types of involvement were identified; parenting, communicating, volunteering, learning at home, decision making, and collaborating with community. Primary school teachers were selected and content analysis was used to make sense of the teachers' narratives. Textual data was analysed using content analysis. The teachers' narratives varied according to their background within the diverse contexts of school environments.

Keywords: parental involvement, teaching and learning; assessment, classroom practice

\section{Introduction}

Throughout the years, a large body of literature has documented the importance of parental involvement in schools. The role of parents has also been recognised in curriculum development in South Africa. Previous studies on parental involvement has been more heavily focused on associations with learner performance, with less attention on how teachers experience parental involvement specifically regarding classroom assessment. Parental involvement does not only refer to helping children with homework. There are a number of activities related to classroom assessment that requires parents to work closely with teachers in order to enrich the child's learning performance. Teachers and parents may also discuss children's behavior at home as well, since behavior problems and social functioning may have immediate consequences for the classroom environment and the teachers' instructional efforts. The aim of this study is therefore to understand teachers' experiences of parental involvement in the context of classroom assessment and to explore the different strategies that teachers employ to encourage parents to participate in classroom activities.

\section{Literature Review}

Parental involvement is often considered a pathway through which schools enhance the achievement of children (EI Nokali, Bachman \& Votruba-Drzal; 2010). Consequently, parental involvement is encouraged by all stakeholders in education; including, teachers, policy makers and researchers. Schools encourage parent involvement by inviting parents to participate in activities at school and facilitating parent-teacher communication.

According to Hartas (2008) parental involvement involves parents' behaviors in home and school settings with intentions to support their children's educational progress. Measures of parent involvement commonly include the quality and frequency of communication with teachers as well as participation in school functions and activities (Turney \& Kao; 2009). Similarly, Villano (2008) argues that parental involvement characterizes parents' values and attitudes regarding education and the aspirations they hold for their children. Although values and attitudes may not directly influence learning objectives and outcomes, they may enhance performance indirectly by promoting children's motivation and persistence in challenging educational tasks.

Parental involvement brings together two key contexts in children's development, namely the home and school settings. Within an ecological framework (Bronfenbrenner; 1992), the home and school contexts are observed as autonomous microsystems whereas parent involvement is conceptualized as a mesosystem, which is made up of interactions between key microsystems. Although each setting can independently influence a child, together the home and school contexts interact to offer a unique influence. Parental involvement is then a product of the interaction between the influences of school and home settings and is necessary for continuity between the two environments 
(Bronfenbrenner \& Morris; 1998). Subsequently, if parents are aware of a teacher's instructional goals, they may provide resources and support for those learning objectives at home. Similarly, in terms of social development, parent involvement may facilitate the development of consistent disciplinary approaches across home and school.

The conceptual framework upon which this study rests is borrowed from Epstein (2008). This scholar identified six types of involvement: "parenting, communicating, volunteering, learning at home, decision making, and collaborating with community". According to the framework, the parenting can be accomplished through education for the parents, support programs, and home visits. Schools can design their own programmes and encourage parental involvement and engagement in learning activities. Communicating, is evident when the parents and teachers work together to discuss what is going on in the classroom with both activities and developments. Communication can therefore be achieved through parent-teacher conferences, newsletters, phone calls and memos, just to name a few. Volunteering refers to parents taking their own time to assist and support their children in any way they can. A few examples could be to volunteer with curricula and extra curricula activities in the classroom. Parents may come into the classroom or school and help the teacher, school staff, or learners in the school. Learning at home is a way in which educators can give parents information they need to help their children with schoolwork, other school activities, decisions, and other social, emotional, and cognitive development and information on required skills for work in the next grade or challenging subjects. Teachers also need to inform parents of what is expected from their children. It is encouraged that school and classroom policies be made available to parents. Decision making requires that families be included in decisions made in school. Activities could be for example, asking a parent to be a representative and a parent leader in a class. In South Africa, establishment of School Governing Bodies are part of the decision making process. Epstein (2008) refers to collaboration, where parents and teachers discover the resources in their community. These resources or services are meant to assist in building stronger programs in the school, family practices, and children's learning. Many of these services are for families to better understand what is available to them for their health and other needs. Various groups could be formed, including services that show what families, social groups can do. Some schools may have summer programs and there may be resources out there to better explain these services and how to utilize them.

The classroom assessment framework in South Africa, leans towards a model of collaboration in teaching, learning and assessment. It proposes a three-way process involving the learner, the educator and the parent in an assessment dialogue (Department of Education; 2011). Examples of such an approach include seeking to elicit parental response to a learner's work in progress and learner-led conferences involving the learner, educator and parent (Mills; 2007).

\section{Research Methodology}

I adopted a narrative case study approach to explore teachers' experiences of parental involvement with regard to classroom assessment. The qualitative design assisted me to understand the diversified practices of the teachers. Three teachers were selected from four different schools in Gauteng Province, in the Tshwane North District of Education in South Africa. The three teachers taught in the Intermediate Phase, in Grades 4, 5 and 6.

\section{Research Finding and Discussions}

The teachers' views are presented and discussed in the following cases;

\subsection{Case 1}

Mapula was a grade 4 class teacher, who has been in the school for thirteen years. Throughout the years, she has been teaching grade 4, 5 and 6. She displayed knowledge of the National Protocol on Assessment. On the issue of parental involvement, Mapula indicated that parents of children in her class displayed a vey low level of involvement and support to her classroom activities. She once complained to the principal about it and she communicated this in the following way;

The principal always tells me I see it the wrong way. He feels the parents are not involved because they are happy and satisfied with what is happening at the school, which I suppose could be true (laughing). He thinks parents are positive and pleased with their children's progress.

Mapula indicated that she sends out parent perusal notes, and asks learners to paste them in their books. She asks parents to go through their children's books with them and to comment on how they think their child is progressing. Some parents comply, in different ways. She expects parents to write quite detailed comments, to discuss with their 
children and engage with them. Most of them always tick "satisfied" and signs, but do not take the trouble to give comments. She gets upset that they do not even write comments such as "This is such beautiful work Mpho, I am so proud of your work Billy, Lerato, I think you need to focus on your handwriting,". On the contrary, Mapula further related that there are some comments that upset her greatly and that some parents take this opportunity to criticise her, as in the case of one parent, "I see in this activity, on the rubric, you gave my child a 1 out of 2, I feel my child should have got a 2 out of 2", without actually focusing on the objectives of the task.

Mapula expressed further:

You know, I was quite upset because anybody looking at this particular work would see that the child cannot get a two out of two, because of the child not meeting the criteria fully. So sometimes the parents use this as a springboard to sort of become personal and actually comment on something that I feel um... they themselves do not have expert knowledge on.

With the assistance of the head of department in the intermediate phase at the school, Mapula compiled another parent perusal note, which was sent out later in the year and on which the teachers were given clear instructions on how it was to be handled. The teachers clearly requested the parents to go through their children's work to assist them, but not to comment about the teacher.

As can be inferred from her claims, Mapula was very upset about comments from some parents. She believed that teaching was the one profession that parents felt they could comment on, irrespective of whether they knew anything about education or not:

I don't think parents do that with doctors, they do not tell doctors what to do with their children when they are sick, or with the mechanic who fix their cars, but for some reason they feel qualified to tell the teachers what to do and how to do it.

Although Mapula admitted that it was only a few parents who did so, she found the comments heartbreaking and demoralising. She did accept, however, instances when a parent did not understand how she came to a particular decision, and she was always willing to provide explanations for her decision-making. Some examples of the comments that made her uncomfortable were: "this is biased; this is unfair; this is your personal opinion". She replied to comments such as these by explaining how she came to a particular conclusion about a particular learner's achievement. She felt that parents were not supporting teachers but rather criticised them, and that they should be coming to school to find out how their children were progressing, and asking how they could contribute positively towards children's learning.

Mapula strived to make parents aware of their children's performance, inviting them to parent evenings, where they had an opportunity to go through their children's work and receive feedback and comments on the report cards. She also indicated that she invites parents to her class throughout the year, to update them regarding their children's work. This was also an element of the school's assessment policy. She preferred to speak to parents on a one-on-one basis. When she noticed children with learning barriers she involved their parents as soon as possible and discussed strategies for assisting them. This was important for her, in order to understand from the parents' side how they observed their children at home. The challenge, however, was that some parents did not respond, even when proper procedures had been followed to make them aware. There were, however, some who were very supportive because they wanted the best for their children as she highlighted:

I once had a problem with one boy in my class, who told his mother every day that he does not have homework. I took it upon myself to design a homework timetable for my class, where parents sign and put the date every day, to acknowledge that the child has work to do. This really helped me to alleviate the problem with learners who do not want to do homework.

\subsection{Case 2}

Hellen was a grade five teacher who had been teaching in the school for ten years, and was the head of the department for the intermediate phase. At the beginning of each term, she issued the assessment plan or programme for the grade to parents. In this plan, learning areas and learning objectives to be assessed were communicated to parents. Learners were generally required to ask their parents to sign their marked tests and return the document to the school. This assisted her in making parents aware of their children's performance. If it was weak she provided the child with another opportunity to improve. She only alerted parents when the case was serious and when she discovered that the child could not cope. She informed parents well in advance if their child was in danger of failing, not coping with the subject, or 
if there were any learning barriers.

Hellen highlighted that some parents were very responsive. It was evident that they helped their children, offered to work with the teacher and kept good contact thereafter. Other parents did not respond to invitations to come and discuss problems relating to their children. Parents who were supportive of the school even went to the extent of organising personal tutors for their children. She believed if partnership between the teachers and the parents was does not exist, this could impede the quality of learning and teaching in the classroom. She felt strongly that parents were responsible for the continuity of learning at home, in being able to supervise homework activities and in supporting their children regarding school requirements.

\title{
4.3 Case 3
}

Dinny was a register class teacher for grade six and had been teaching at the school for seven years. She indicated that parental involvement in her class was minimal. She had forty-six learners in her class and only about five responded to invitations to visit the school. Her school was situated in an informal settlement and she attributed this to the fact that most parents were very young, some either had other small babies and some were working in town. At the time of the interview, she still had reports from the previous term that some parents did not collect, simply because they could not come to the school. These parents were not aware of anything that happened in the school and as such could not support their children. Overall, parents were ignorant and uninterested in what was going on in the school. Children came to school with inappropriate uniform and teachers could not meet with the parents to resolve this issue. Parents had been informed about school rules and regulations but they did not fulfil their obligations. The school was static financially, with photocopiers dysfunctional and irreparable because of financial constraints.

Dinny mentioned an intervention form from the department that was used in her school to classify learners with barriers to learning. She indicated that when a learner failed a grade, it was recommended that the parents together with the teacher fill in this form. The teacher filled in details of non-achievement of learning objectives as well as other areas in which the learners had challenges, in consultation with the parents. She was concerned that because of lack of parent participation in this process, teachers would just fill in these forms without exploring other means of helping learners achieve learning objectives. She believed that with the parent's involvement, children could still be given extra opportunity in reading, speed tests and other projects. She expressed the opinion that she was not in favour of the intervention form:

\begin{abstract}
During my schooling years, there was no intervention form. We had memory lessons, times tables, recitations, songs and rhymes that we practiced every day. When you could not read you were given a list of words to practise at home as well as storybooks. Our parents were not educated, but were able to make sure that we do our school work. Surprisingly, parents these days are well educated and some even occupy senior positions at work, but for some reason they are not able to assist their children.
\end{abstract}

She had a few learners who had reading barriers in her class. They could not read even when she tried hard to support them. She discussed the matter with the parents and together they developed strategies for intervention. She gave the parents some extra reading activities so that they could assist their children, and as time went on she noticed that those learners' reading had improved.

\section{Conclusion}

Based on the evidence gleaned from the interviews and conversations with the teachers, parental involvement is a challenge. Some parents are not involved in their children's school activities, except for a few who had the interest of their children's education at heart. The teachers mentioned that attendance at general parent meetings was poor and that most parents did not assist their children with schoolwork and were uncooperative. The teachers had the impression that they felt it was solely the responsibility of the teacher to educate their children and they felt burdened by the additional work that they had to do at home with their children. However, contrary to what the participants stated, there was evidence to suggest that some parents were involved in school activities and in contributing towards improved performance. These were parents who were responsive and kept good contact with teachers and even went to the extent of hiring private tutors to help their children at home.

Literature has documented that parental involvement is an intergral component of a learners' life. Beased on evidence from interviews with teachers in this study, the amount of participation that parent's give can contribute towards effective teaching and learning. Through the school and home connection, children understand that their parents are 
concerned about their education, and this in turn could enhance continued motivation and self-confidence (Adamski, Fraser \& Peiro (2013). It is the responsibility of the school to ensure that a positive relationship between parent and teacher is established and that children's best interests are being met. It should be acknowledged, however, that there are obstacles that prevent parents from being more involved in their children's education, such as time and lack of education. As Addi-Raccah \& Ainhoren (2009) posits, schools therefore need to work around these issues and implement effective strategies to encourage parental involvement.

\section{References}

Adamski A, Fraser BJ., \& Peiro, MM. (2013). Parental involvement in schooling, classroom environment and student outcomes. Learning environment Research, 16: 315-328.

Addi-Raccah, A., \& Ainhoren, R. (2009). School governance and teachers' attitudes to parents' involvement in schools. Teaching and Teacher Education, 25(6), 805-813.

Bronfenbrenner, U. (1992). Ecological systems theory, in R Vasta (ed). Six theories of child development: revised formulations and new trends. London: Jessica Kingsley:187-249.

Bronfenbrenner, U \& Morris, PA. (1998). The ecology of human developmental processes, in RM Lerner (ed). Handbook of child psychology. Volume 1: theoretical models of human development. New York: John Wiley \& Sons: 993-1027.

Department of Education, (2011). National Curriculum Statement (NCS). Curriculum and Assessment Policy Statement (CAPS), English Home Language, Intermediate Phase, Grades 4-6, Pretoria, South Africa.

Epstein, J. K (2008). Improving family and community involvement in secondary schools. The Education Digest, 73 (6), 9-12.

El Nokali, NE., Bachman, HJ., \& Votruba-Drzal, E. (2010). Parent Involvement and Children's Academic and Social Development in Elementary School. Child Development, 81 (3): 988-1005.

Hartas, D. (2008). Practices of Parental Participation: A Case Study. 24 (6), 139- 153.

Mills, G. (2007). Action research: A guide for the teacher researcher (pp. 5, 50, 84-86, 94, 138) Upper Saddle River, NJ: Pearson Education, Inc. 51

Turney, K., \& Kao, G. (2009). Barriers to School Involvement: Are Immigrant Parents Disadvantaged? 102(3\&4), 257-271.

Villano, Matt (2008). Meet the Parents. 35(4), 48-52. 